\title{
Normalized Difference Vegetation Index Analysis of the first part impacted with the breaking of the Fundão Dam in Mariana-MG
}

\author{
Análise do Índice de Vegetação por Diferença Normalizada da primeira parte \\ impactada com o rompimento da Barragem Fundão em Mariana-MG
}

\author{
Renan Valério Eduvirgem' \\ Claudemir Rodrigues Soares" \\ Elissandro Voigt Beier"II
}

\begin{abstract}
This paper addresses the exploitation of mineral resources and suggests that an environmental management that meets a set of measures and mutual cooperation between public and private managers, civil society, and mining companies that exploit natural, renewable, and non-renewable resources is needed. Cooperation between managers and joint safety measures can prevent present and future accidents like the one that occurred in Mariana City in Minas Gerais State (MG). The questioning presented puts into discussion the disaster that occurred in Mariana City due to the rupture of the ore tailings dam (Fundão dam) in November 2015. With an estimated population of 60,000 inhabitants, Mariana City has a local economy directly linked to mining activities. Due to the impact caused by the rupture of the Fundão dam, both city and vegetation were destroyed, among other factors observed along the path followed by the tailings. However, what is discussed in this article with greater emphasis is the loss of vegetation in the watershed. The methodology compared the degree of vegetation coverage in the basin area through the analysis of the Normalized Difference Vegetation Index NDVI for 2013, 2016, 2017, 2018, and 2019 in different months. Some images refer to August and other samples are from September, complementing the process through the use of Landsat 8 satellite images - OLI sensor, acquired from the United States Geological Survey (USGS) repository. 299 points were distributed in the quadrant to perform the analyses $(n=299)$. The level of significance was set at $5 \%$ with a $95 \%$ confidence, to ascertain and verify whether the data distribution is in an acceptable condition (dense or semi-dense vegetation cover). Regarding vegetation analysis, the Kolmogorov-Smirnov and Shapiro-Wilk tests were used. Both tests indicated a non-normal distribution for the NDVI data set, which indicates the absence of a vegetation index that was covered by the tailings, resulting in an area with large spaces without the coverage previously registered in 2013. We conclude that the vegetation suffered a drastic alteration provoked by the rupture of the Fundão dam which also led to homeless residents, negative impacts on the livelihood of the small farmers and fishermen, silting up of rivers and streams, death of several animal and plant species, and also affected the ecosystem and the local and regional biodiversity.
\end{abstract}

\footnotetext{
'Universidade Estadual de Maringá, Maringá, PR, Brasil - georenanvalerio@gmail.com.

"Universidade Estadual de Maringá, Maringá, PR, Brasil - rodrisoaresmi@gmail.com.

I"Universidade Estadual de Maringá, Maringá, PR, Brasil - elissandrovoigt@hotmail.com
} 
Keywords: Risks; Environmental disasters; Tailings dams.

\section{Resumo}

O artigo aborda a exploração de recursos minerais e, sugere que é preciso uma gestão ambiental que atenda um conjunto de medidas e de cooperação mutua entre gestores públicos e privados, a sociedade civil e as empresas mineradoras que exploram os recursos naturais, renováveis e não renováveis. A cooperação entre gestores e as medidas de segurança conjuntas podem prevenir presentes e futuros acidentes como em MarianaMG. O questionamento apresentado coloca em discussão o desastre ocorrido no município de Mariana-MG, em decorrência do rompimento da barragem de rejeitos de minérios (barragem de fundão), em novembro de 2015. A população da cidade, entorno de 60.000 habitantes e, a economia local ligada diretamente com a atividade mineradora. A partir do impacto, causado pelo rompimento da Barragem de Fundão, observa-se a destruição da cidade e da vegetação, entre outros fatores observados ao longo do trajeto percorrido pelos rejeitos, mas o que se discute no artigo com maior ênfase é a perda da vegetação na bacia hidrográfica. A metodologia comparou o grau de cobertura da vegetação na área da bacia, por meio da análise do Normalized Difference Vegetation Index - NDVI, para os anos de 2013, 2016, 2017, 2018 e 2019, em diferentes meses, algumas imagens remetem a agosto e outras amostras são de setembro, complementando o processo por meio de tratamento das imagens de satélite Landsat 8 - sensor OLI, adquiridas no repositório da United States Geological Survey (USGS). Foram distribuidos 299 pontos no quadrante em questão para promover as análises $(n=299)$. Adotouse o nível de significância de $5 \%$ e confiança de $95 \%$, para averiguação e constatação se a distribuição dos dados se encontra na condição aceitável (cobertura vegetal densa ou semi-densa) para vegetação, utilizou-se os testes Kolmogorov-Smirnov e Shapiro-Wilk. Ambos os testes apontaram distribuição não normal para o conjunto de dados de NDVI o que indica a ausência de índice de vegetação que foi encoberta pelo rejeito, resultando em uma área com grandes espaços sem a cobertura anteriormente registrada no ano de 2013. Concluímos que a vegetação sofreu uma alteração drástica, provocada pelo rompimento da barragem de fundão, provocando incidentes, destaca-se: moradores desabrigados, afetou o sustento dos pequenos agricultores e pescadores; causou assoreamento de rios e córregos; provocou a morte de diversas espécies animais e vegetais; afetou o ecossistema e a biodiversidade local e da região.

Palavras-chave: Riscos; Desastres ambientais; Barragens de rejeitos. 


\section{Introduction}

This research was supported by available studies and bibliographic materials, such as academic articles, books, theses, and dissertations that served as a basis to carry out the study developed and presented in this article. The article proposes to evaluate the loss of vegetation using the Normalized Difference Vegetation Index (NDVI) through remote sensing. This technological procedure allows data to be collected from a specific place and region, that is, without direct contact with the location allowing for gathering of the information remotely.

The NDVI is an index that seeks to analyze the situation of the vegetation collected through remote sensing. With the application of the index, it is possible to observe the extent and proportion of the effects produced by the rupture of the Fundão dam. The event not only impacted the environment but also reached the political and administrative limits of the territories. This is the reason why it is essential to take measures to combat the disordered and exploratory use of natural resources, and at the same time, contribute to reduce the damage to the environment attributed to human mining activities Borges (2018).

This theme needs to be addressed in political, scientific, and social discourses, since the incident caused damage to a large area of the country due to the rupture of the dam. Mining activities for exploration and removal of soil resources can cause incalculable damage to historical, social, economic, and cultural heritage. The heritage built over the years by the local population can be wiped out in a few seconds by the volume of tailings caused by the rupture of dams and devastate almost all of its memory, history, and the identity of this community as highlighted by Gonçalves. et al. (2015). So it is necessary to ask some questions to the managers such as: How to prevent? How to avoid accidents of this proportion? What measures should be taken to prevent accidents with dams?

The measures taken for prevention must be periodically approached by technical professionals, according to the types of risks and the possible potential damage close to urbanized places. This procedure aims to monitor problems or anomalies which may affect and damage the dam. Regions of broad biological importance are prone to serious environmental accidents and, therefore, it is necessary to avoid the lack of maintenance in the facilities and also make routine inspections to identify potential risks to determine preventive 
or corrective measures to be taken in by the entrepreneurs, as emphasized by Mendes and Espindola (2018).

The Law No. 12,334 of September 20, 2010 establishes the National Policy for the Safety of Dams for the accumulation of water for any use, the final or temporary disposal of tailings, and the accumulation of industrial waste. This law created the National Information System on Safety of Dams and changed the wording of article 35 of Law N. 9,433 of January 8, 1997, and of article 4 of Law 9.984 of July 17, 2000. In article 1, this law establishes the National Dam Safety Policy (PNSB) and creates the National Dam Safety Information System (SNISB), making it responsible for inspection of mining tailings dams in charge of the National Department of Mineral Production (DNPM) linked to the Ministry of Mines and Energy.

In item 1 of Article 2 of Law 12.334 / 2010, dam is defined as any structure in a permanent or temporary water course for the purpose of containing or accumulating liquid substances or mixtures of liquids and solids, comprising both the bus and the associated structures. In Article 2, the law also deals with the dam and associated structures, emphasizing in item II that the reservoir is intended for the unnatural accumulation of water and other liquid or solid substances; item III deals with dam safety in terms of structural and operational condition and preservation of the environment; item IV regards private or governmental agent with the right to operate the dam; item $V$ establishes the inspection body which is the authority of the public power; risk management stands out in item VI which deals with normative actions; and item VII reinforces the potential damage associated with the dam such as rupture, leakage, soil infiltration, or dam malfunction, Brasil Planalto (2020).

The causes of environmental accidents can possibly be avoided as long as there is a responsible supervising over the developments. However, if the inspection and the disaster prevention plan fails, the environmental damage can be of great proportions for the local population and the environment, as highlighted by the authors Llory and Montmayeul, (2014); Daniellou et al., (2010).

Geotechnologies along with remote sensing techniques and linked to Geographic Information Systems (GIS) are fundamental to map changes in the landscape. In fact, through GIS, it is possible to monitor the dams by remote mapping, and doing so, prevent environmental accidents of great magnitude such as the Fundão dam disaster in Bento 
Rodrigues subdistrict $35 \mathrm{~km}$ from the city center of Mariana-MG on November 5, 2015. As a consequence due to the dam burst, there was a flood of mud and mining waste.

The robustness of the vegetation prior to the accident is no longer seen but rather a trail of destruction through which the mud passed modifying the entire local and regional landscape, which also suffered a change in the landscape. In fact, the path taken by the tailings has come a long way, invaded other states, and entered the ocean. The lack of plants observed on the maps is related to the areas impacted by the accident in Mariana City. The Vegetation Indices, in addition to the Normalized Difference Vegetation Index (NDVI), made it possible to show the behavior of the vegetation and the destruction left by the accident as shown by Zanzarini (2013) and Lourenço and Landim, (2004).

Thus, this study aims to analyze the spatiality of the incident so that the methodology that was applied, linked to other analysis materials, can assist in the delimitation procedure of the impacted areas. When choosing the method to be adopted, it is necessary to be clear what you intend to answer, in this case, about the decimated vegetation and the environmental impact generated by the phenomenon or other factors to be explored in the research through the choice of the method. Freitas and Magalhães ( 2012) present some methods of vegetation assessment such as methods and parameters for studying vegetation with an emphasis on Arboreal extract, method per quadrant, fixed plots, random sampling, among other vegetation assessment methods.

As the accident proportions were of a large scale, these methods were not applied to the study. Therefore, the remote sensing and the application of the NDVI index were chosen to develop this paper. In fact, this study was carried out using images from the Landsat 8 satellite - OLI sensor and the images were acquired in the United States Geological Survey (USGS) repository.

Ortiz and Freitas (2005) used remote sensing and geoprocessing to spatialize and quantify the changes produced by man in nature using (GIS). In this way, the authors observed, through the methodology applied, damage to the environment and vegetation around the city of Rio Claro in São Paulo State. There are so many other methods, but as previously mentioned by authors such as Freitas and Magalhães (2012), Ortiz and Freitas (2007) and Lourenço and Landim, (2004), it is necessary to choose the method that best fits the interests 
of the research and the location chosen to carry out the study, that is, in the field trip (on site) or in an office.

Martim and Santos (2013 p. 3250) point out that the "methodological lines for assessing environmental impacts are structured mechanisms for comparing, organizing, and analyzing information about these impacts arising from any activity, including the means of written and visual presentation of this information". The authors evaluated the environmental impacts in a copper mining company using the interaction network method to assess environmental impacts in a mining company and identified the activities that generate the greatest number of environmental impacts in the extraction of ore. The analysis using the method and methodology applied in the study, according to the authors, can be used as a diagnostic tool to adopt measures for the prevention or correction of negative impacts on the environment promoting sustainability.

Thus, this study is related to the impacts caused by the rupture of the Fundão dam in Mariana City and it was carried out in an office. The choice of the work method by remote sensing using the NDVI vegetation index was considered the most appropriate for the moment due to the impossibility of getting to the research site. The vegetation index met the expectations of the study which, in addition to showing the destruction of vegetation, also presented other facts (social, economic, and cultural) presented in the study.

\section{Methodological procedures}

\subsection{Location and description of the area}

Mariana City in Minas Gerais had a population estimate of 60,724 inhabitants for 2019 (IBGE, 2020), with a population growth of approximately $10.71 \%$ compared to the last census. Regarding hypsometry, the city presented a minimum of $421 \mathrm{~m}$ to the east and southeast. The highest altimetric levels were determined from north to south at the west end; the maximum value found was $2,068 \mathrm{~m}$. The amplitude was $1,641 \mathrm{~m}$. In the highlighted area, the amplitude is lower and more homogeneous in relation to the whole with a sharp decline from northwest to southeast (Figure 01). In order to understand the displacement of the tailings, it is crucial to visualize the elevation dimensions of the area. 
Regarding the declivity of Mariana-MG, a variation of $0-15.32 \%$ was found at percentages greater than $56 \%$. However, the slope classes are distributed practically homogeneously throughout the city. In the study area, the slope tends to increase from west to east (Figure 02). Nevertheless, with the rupture of the Fundão dam, the tailings went from west to east. This fact occurred due to physiographic conditions as can be seen in figure 03 . The vegetation in the impacted area corresponds to the Atlantic Forest (Silva; Ferreira; Scotti, 2015).

Figure 01 - Hypsometry of Mariana, Minas Gerais

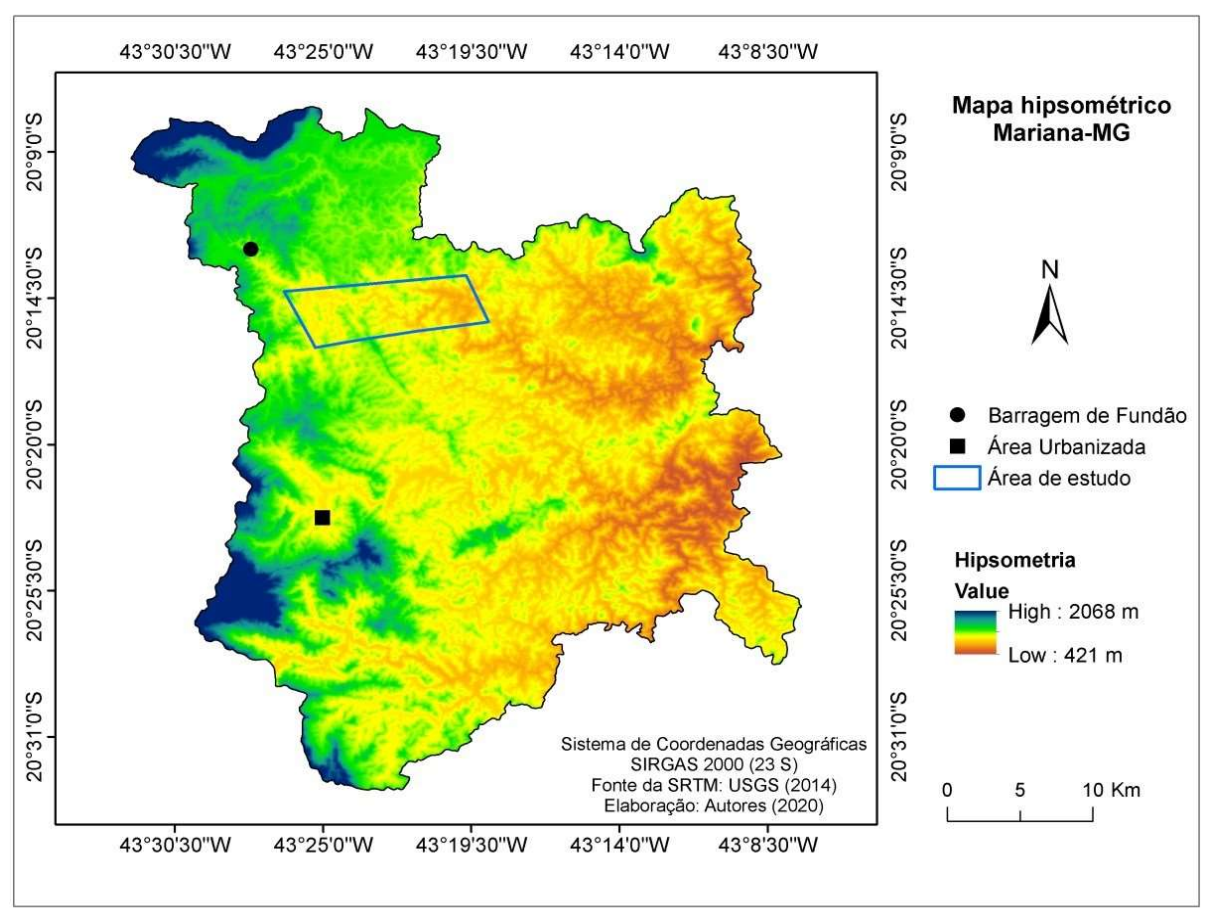

Figure 02 - Declivity of Mariana, Minas Gerai 


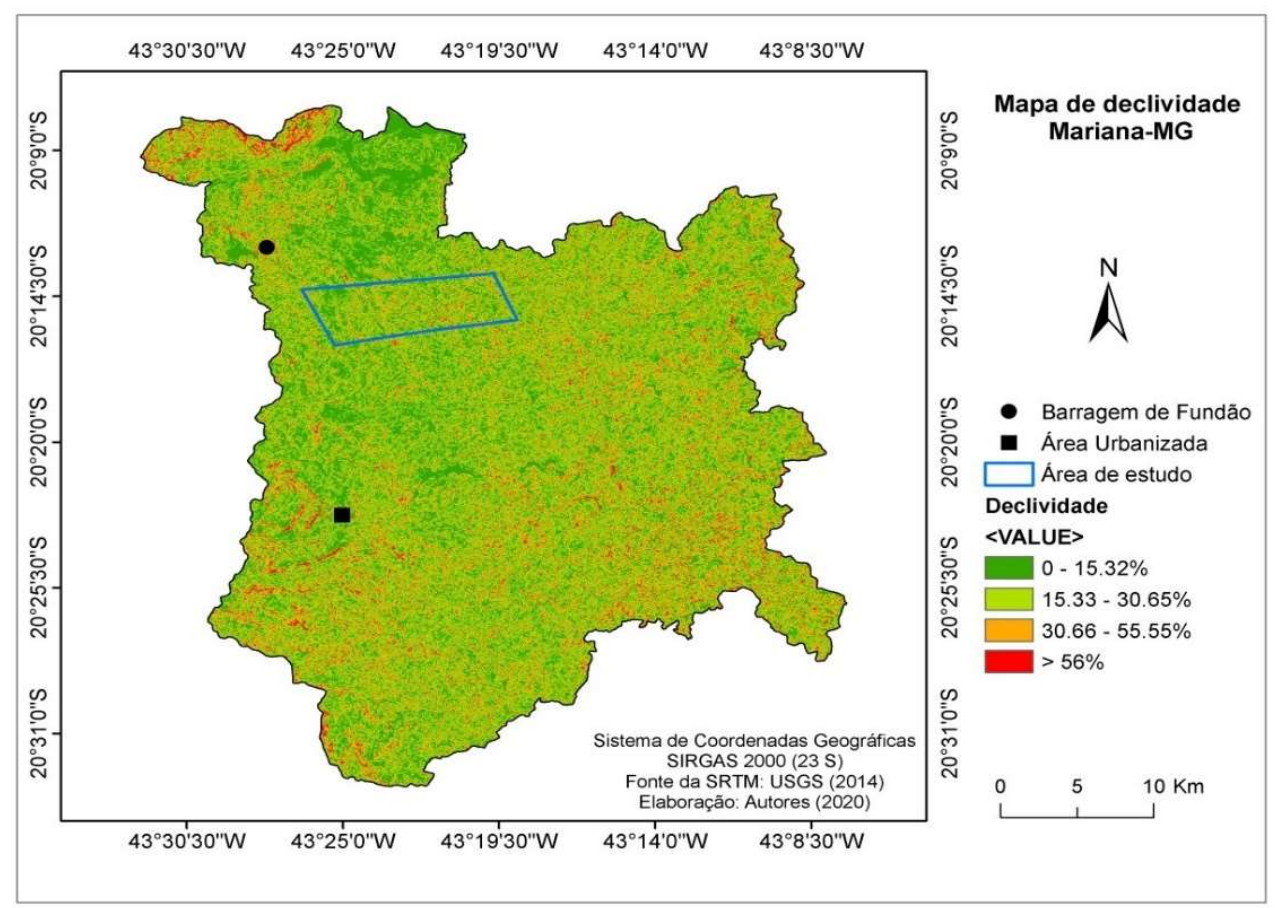

Figure 03 - Colored composition (RGB 4-3-2) with emphasis on the study area

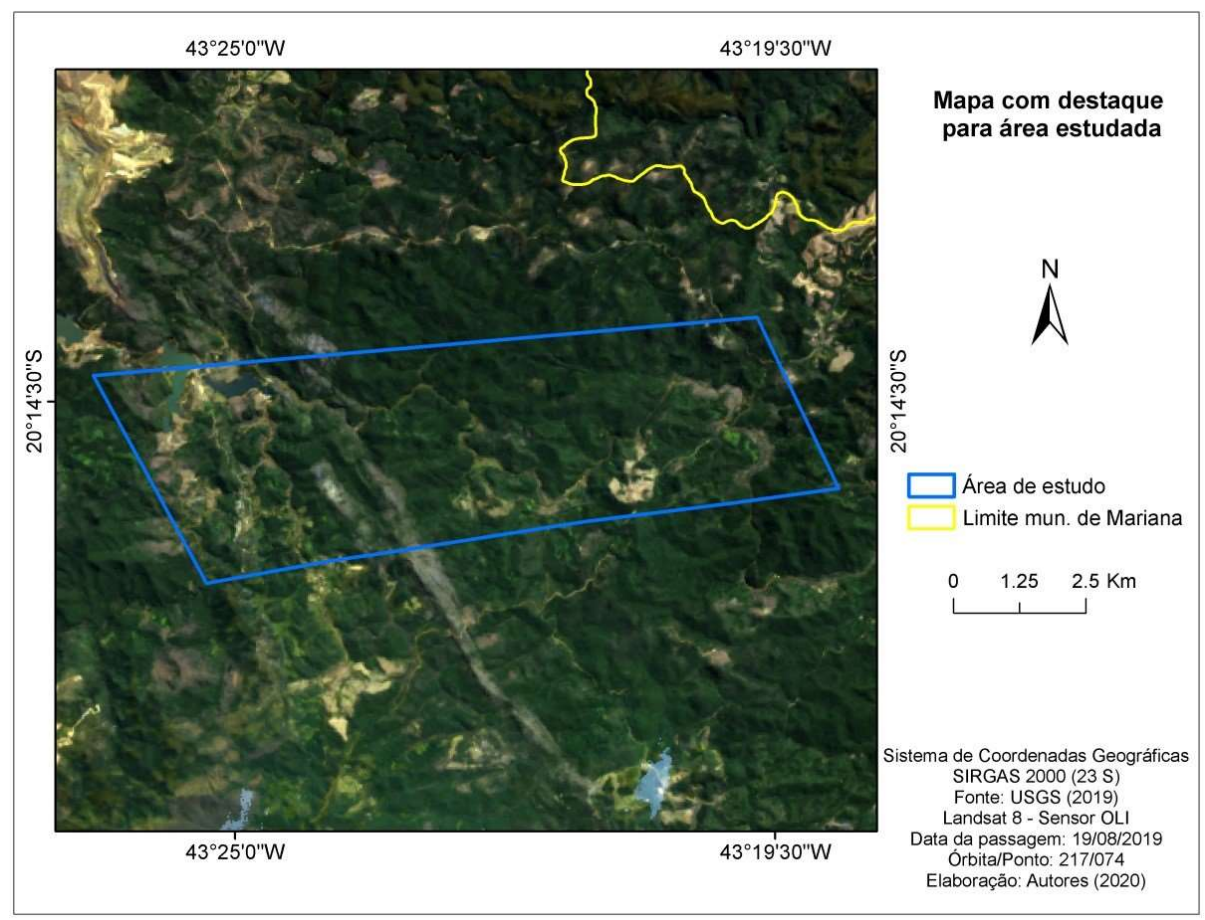

\subsection{Selection of satellite images and treatment}


The study was performed using images from the Landsat 8 satellite - OLI sensor in order to generate the NDVI of the following dates: 08/02/2013, 09/11/2016, 08/29/2017, $09 / 01 / 2018$, and 08/19/2018 / 2019. The SRTM was on 09/23/2014. The images were acquired from the United States Geological Survey (USGS) repository. The scenes from Landsat 8 were listed for their gratuity and mainly for the quality of the images and the appropriate resolution for the purpose of the study. The years for the analysis of the area are justified by 2013 being before the disruption that occurred in 2015, for mapping the NDVI values before the vegetation degradation, and the remaining years for monitoring the possible vegetation regeneration.

Radiometric calibration was also performed which refers to the conversion of the Digital Number (ND) of the image pixels into monochromatic spectral radiance, in accordance to Equation 1.

$L \lambda=M L Q c a l+A_{L}$

Where:

$\mathrm{L} \lambda$ is the monochromatic spectral radiance $\mathrm{W} \mathrm{m}^{-2} \mathrm{sr}^{-1} \mu \mathrm{m}^{-1}$;

$M L$ is the multiplicative factor of each band;

$A_{L}$ is the addition coefficient found in the metadata file;

$Q_{c a l}$ are the digital numbers (DN) corresponding to each band in the image.

The monochromatic reflectance was calculated with the OLI sensor bands, converted to planetary reflectance using the reflectance rescheduling coefficient informed in the image metadata file (MTL file) through Equation 2.

$\rho \lambda^{\prime}=M \rho Q c a l+A \rho$

However, it is necessary to correct the reflectance according to the zenith angle. In order to do so, Equation 3 was used.

$\rho \lambda=1+\frac{\rho \lambda^{\prime}}{\cos \left(0_{S Z}\right)}+\frac{\rho \lambda^{\prime}}{\sin \left(0_{S E}\right)}$

Where:

$\rho \lambda$ is the planetary reflectance, with correction of the zenith angle;

$0_{S E}$ is the solar elevation angle present in the MTL file; 
$0_{S Z}$ is the solar zenith angle which is calculated according to the MDU.

\section{NDVI INDEX}

The enhancement of vegetation by NDVI takes into account the relationships between the reflectance of the soil and the vegetation. In fact, the vegetation has a high reflectance in the near infrared region, whereas the soil has a high reflectance in the red region. Thus, the higher the densities of the vegetation cover, the lower the reflectance in the visible region red. However, the reflectance in the near infrared region will be higher. For the calculation of NDVI, Equation 4 was used:

$N D V I=(\rho N I R-\rho R E D) /(\rho N I R+\rho R E D) \quad(E q .4)$

Where:

NDVI is the Normalized Difference Vegetation Index;

pNIR is the reflectance in the near infrared band;

PRED is the reflectance in the red band.

The values obtained in NDVI varied between +1 to -1 , in which, the closer to -1 , the lower the density of the vegetation cover, and the closer to +1 , the greater the density.

\subsection{Statistical analysis}

The IBM SPSS $22{ }^{\circledR}$ software was used for the statistical analysis. 299 points were distributed in the quadrant under study to promote the analyses $(n=299)$. To reach $n$ (sample), equation 5 was used based on the number of pixels $(N)$. It should be noted that the equation uses the standardized normal distribution table. The significance level of $5 \%$ and 95\% confidence were adopted.

$N D V I=(\rho N I R-\rho R E D) /(\rho N I R+\rho R E D)$

Where:

NDVI is the Normalized Difference Vegetation Index;

pNIR is the reflectance in the near infrared band;

pRED is the reflectance in the red band. 
The values obtained in NDVI varied between +1 to -1 , in which, the closer to -1 , the lower the density of the vegetation cover, and the closer to +1 , the greater the density.

\subsection{Statistical analysis}

The IBM SPSS $22{ }^{\circledR}$ software was used for the statistical analysis. 299 points were distributed in the quadrant under study to promote the analyses $(n=299)$. To reach $n$ (sample), equation 5 was used based on the number of pixels $(N)$. It should be noted that the equation uses the standardized normal distribution table. The significance level of $5 \%$ and 95\% confidence were adopted.

$n_{0}=\frac{1}{4} \cdot\left(\frac{Z_{\propto / 2}}{e_{0}}\right)^{2}$

Where:

$n_{0}$ is the sample size without the correction factor;

$Z_{-}(\propto /)$ is the value calculated based on the $Z$ test;

$e_{0}$ is the probability of the value found is not true.

When the population size $(\mathrm{N})$ is finite, that is, less than 10,000 , the correction factor must be used (Equation 6).

$n=\frac{N \cdot n_{0}}{N+n_{0}-1}$

Where:

$n$ is the sample size with correction factor;

$\mathrm{N}$ is the statistical universe;

$n_{0}$ is the sample size without the correction factor.

To determine whether the data distribution is normal, the Kolmogorov-Smirnov and Shapiro-Wilk tests were used. Both tests showed non-normal distribution for the NDVI data set. Thus, the hypothesis $\mathrm{H} 1$ of the test was accepted. This fact is also confirmed by the random points around the line in figure 04.

Libardi et al. (1996) recommend promoting exploratory data analysis with the purpose of confirming normality tests and understanding the data distribution. 
Figure 4 shows that the data set is not normal. Accordingly, figure 05 also shows the non-normality of the data, highlighting a high number of outliers and extreme values.

In order to verify if there are differences between the NDVI for each year worked in this study, the Friedman test - non-parametric test was used.

The test statistic (called $x^{2}$ ) is given by Equation 7 :

$x^{2}=\frac{12}{n k(k+10)} \sum_{i=1}^{k}\left(R_{i}\right)^{2}-3 n(k+1)$

Where:

$\mathrm{N}$ is the number of lines;

$\mathrm{K}$ is the number of columns;

$R_{j}$ the sum of the orders in the column.

This variable follows a Chi-Square distribution with k-1 degrees of freedom.

If the probability obtained by this method does not exceed $\alpha, \mathrm{H}_{0}$ is rejected.

$\mathrm{H}_{0}$ : the distributions of NDVI values do not differ;

$\mathrm{H} 1$ : the distributions of NDVI values are different.

(...)

Figure 04 - Accumulated probabilistic distributions. A) NDVI 2013, B) NDVI 2016, C) 2017, D) 2018, E) 2019 

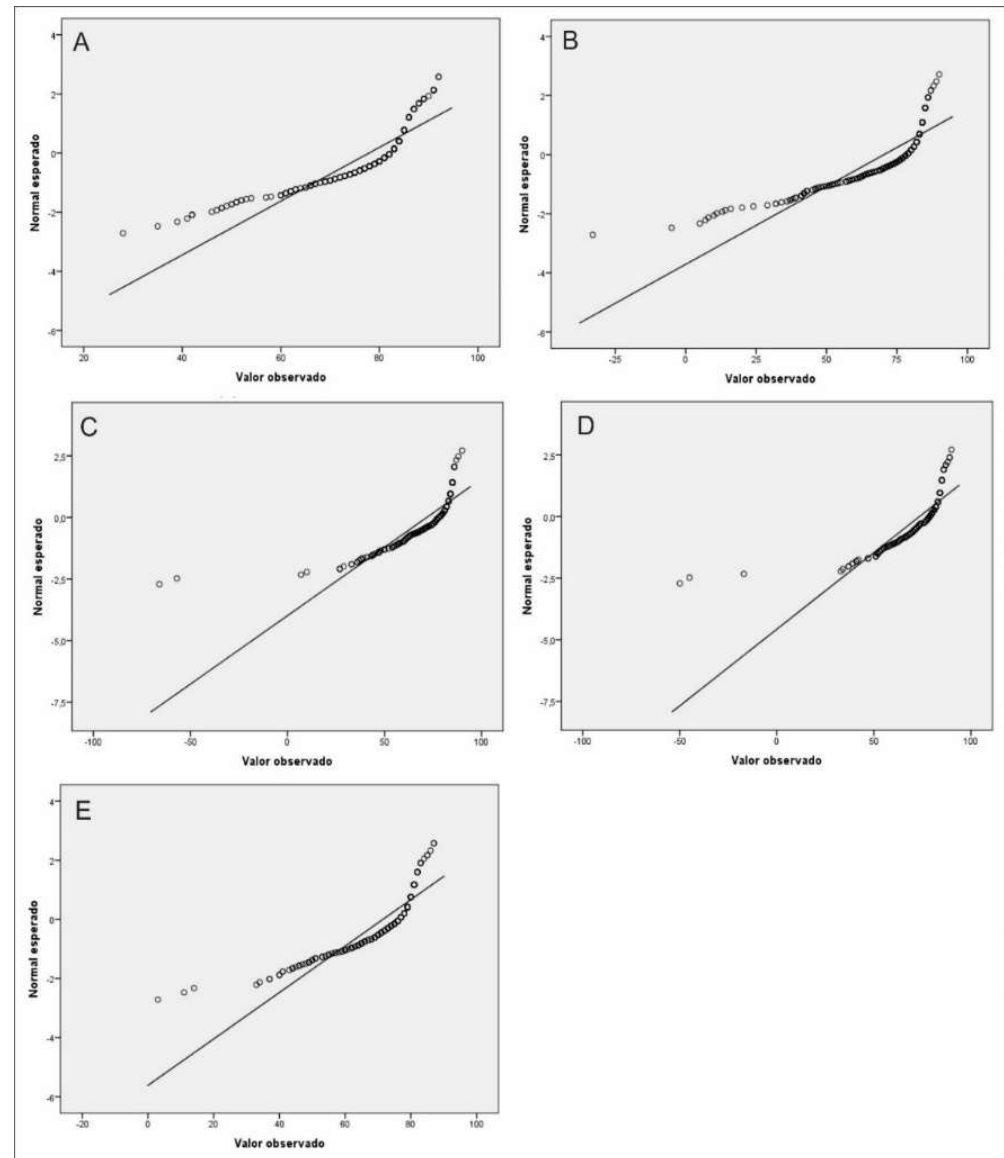

Figure 05 - Data set boxplots

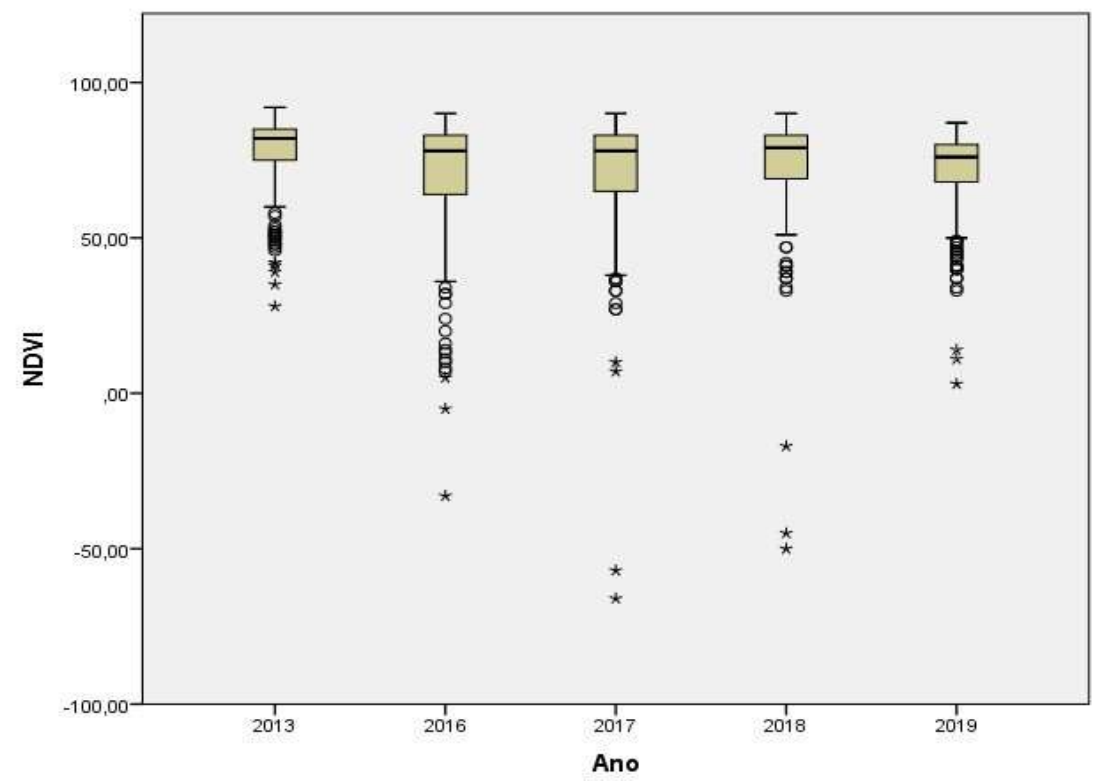

\section{Results and Discussion}


With the rupture of the Fundão dam in November 2015, the destruction of part of the Bento Rodrigues sub-district located northwest of the quadrant under study occurred, as can be seen in the differences between 2013 and 2016 (Figure 06). The same figure also shows the arrival of tailings in the Rio Gualaxo do Norte City. Accordingly, Mendes and Espindola (2018) evaluated that the impacts caused by the rupture of the dam in the sub-district of Bento Rodrigues and its surroundings were greater than $50 \%$ of the area.

With NDVI, it became possible to promote the identification of changes in water courses. There was also an increase in tailings mainly in the course of the Gualaxo do Norte River, when comparing the images from 2013 (before the dam burst) with the others. Over the years, the class that determines water was ascending, but with lower values in the comparative percentage from 2013 to 2019 (Table 01). However, this increase occurred in the northwestern part of the area, indicating accumulation; nonetheless, in 2013 the distribution occurred by the aforementioned river. Nevertheless, this river showed a decrease in tailings amount from 2016 to 2019, but it does not meet the spectral response that was in 2013 (Figure 07). Silva, Carvalho and Cruz (2018) determined that the impacted area was $8.25 \mathrm{~km} 2$ with 34 million cubic meters of iron ore tailings.

Iron ore tailings are extremely harmful to soil and vegetation (Ribeiro Filho et al., 1999). Foesch (2017) also identified an abnormality in the spectral behavior of water in river beds in Mariana-MG, determining the impact by sediments rich in heavy metals through physical-chemical analyzes.

Figure 06 - Study area in 2013 and 2016 showing the arrival of mud with tailings in the Gualaxo do Norte River 


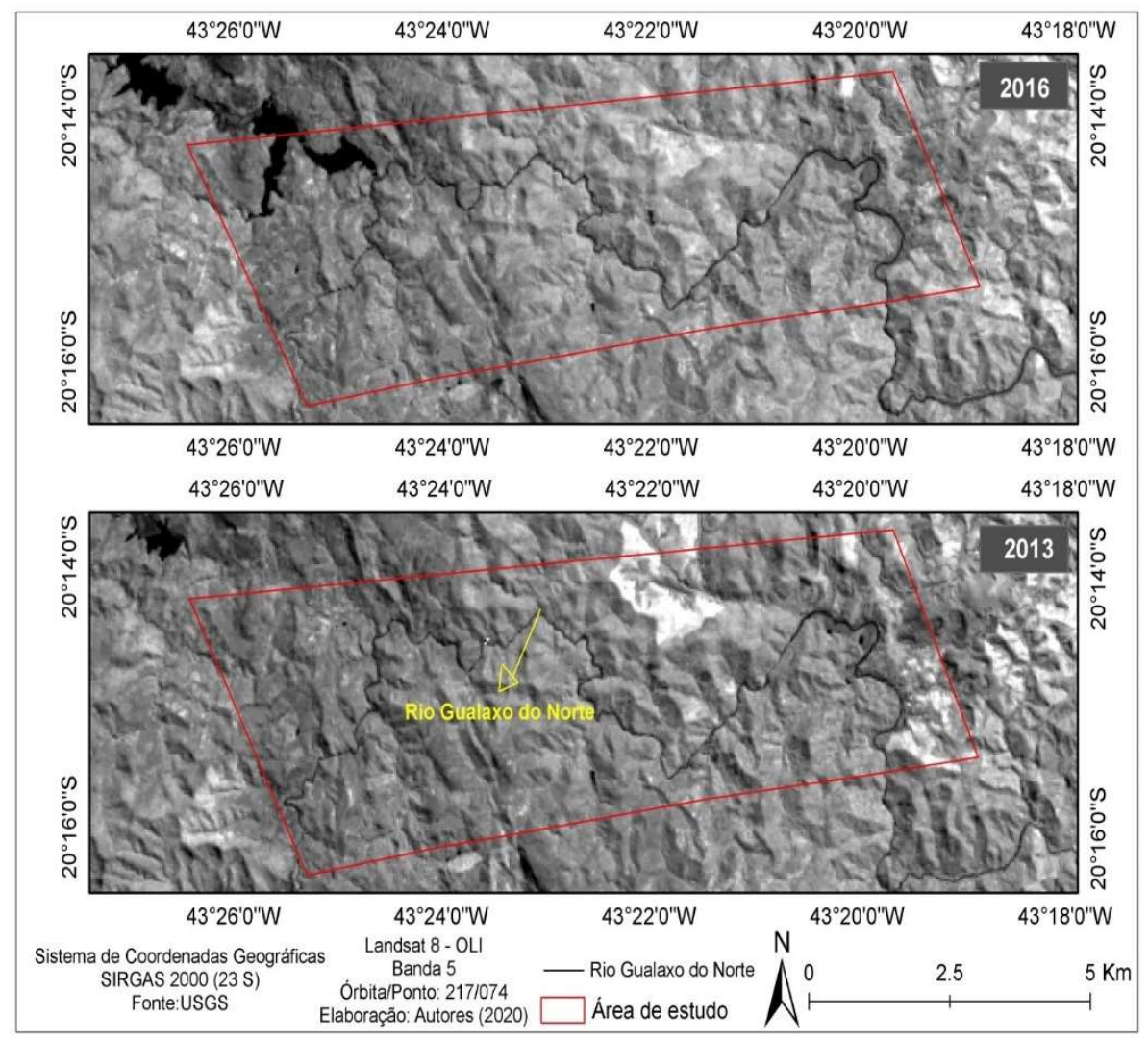

Table 01 - \% of area corresponding to each class of NDVI

\begin{tabular}{|c|c|c|c|c|c|c|c|}
\hline \multicolumn{8}{|c|}{$\%$ of area corresponding to each NDVI class } \\
\hline Classes & 2013 & 2016 & 2017 & 2018 & 2019 & Total & By type \\
\hline Water & 1.66 & 0.44 & 0.91 & 0.97 & 1.16 & 5.12 & \multirow[b]{2}{*}{7.1} \\
\hline $\begin{array}{l}\text { Water / sediment / } \\
\text { tailings }\end{array}$ & 6.52 & 6.68 & 4.28 & 5.13 & 7.80 & 30.41 & \\
\hline Vegetation pothole & 12.80 & 11.13 & 14.04 & 13.92 & 12.57 & 64.46 & \multirow{3}{*}{92.9} \\
\hline Less dense vegetation & 25.42 & 21.53 & 23.22 & 25.58 & 21.19 & 116.95 & \\
\hline $\begin{array}{c}\text { More dense } \\
\text { vegetation }\end{array}$ & 53.60 & 60.22 & 57.56 & 54.40 & 57.28 & 283.06 & \\
\hline
\end{tabular}

The increase in the orange class - in the comparison of the years 2013 and 2019 - plus the spatial analysis, indicate a possible difficulty in regenerating tree vegetation, especially on the banks of the Gualaxo do Norte River (Figure 07). It can also be seen in the image that the least affected area is located in the central-north region, which consists predominantly of tree vegetation at altitudes higher than the impacted area, thus containing the highest NDVI values (Figure 07). 
Figure 07 - Normalized Difference Vegetation Index (NDVI) map of the study area

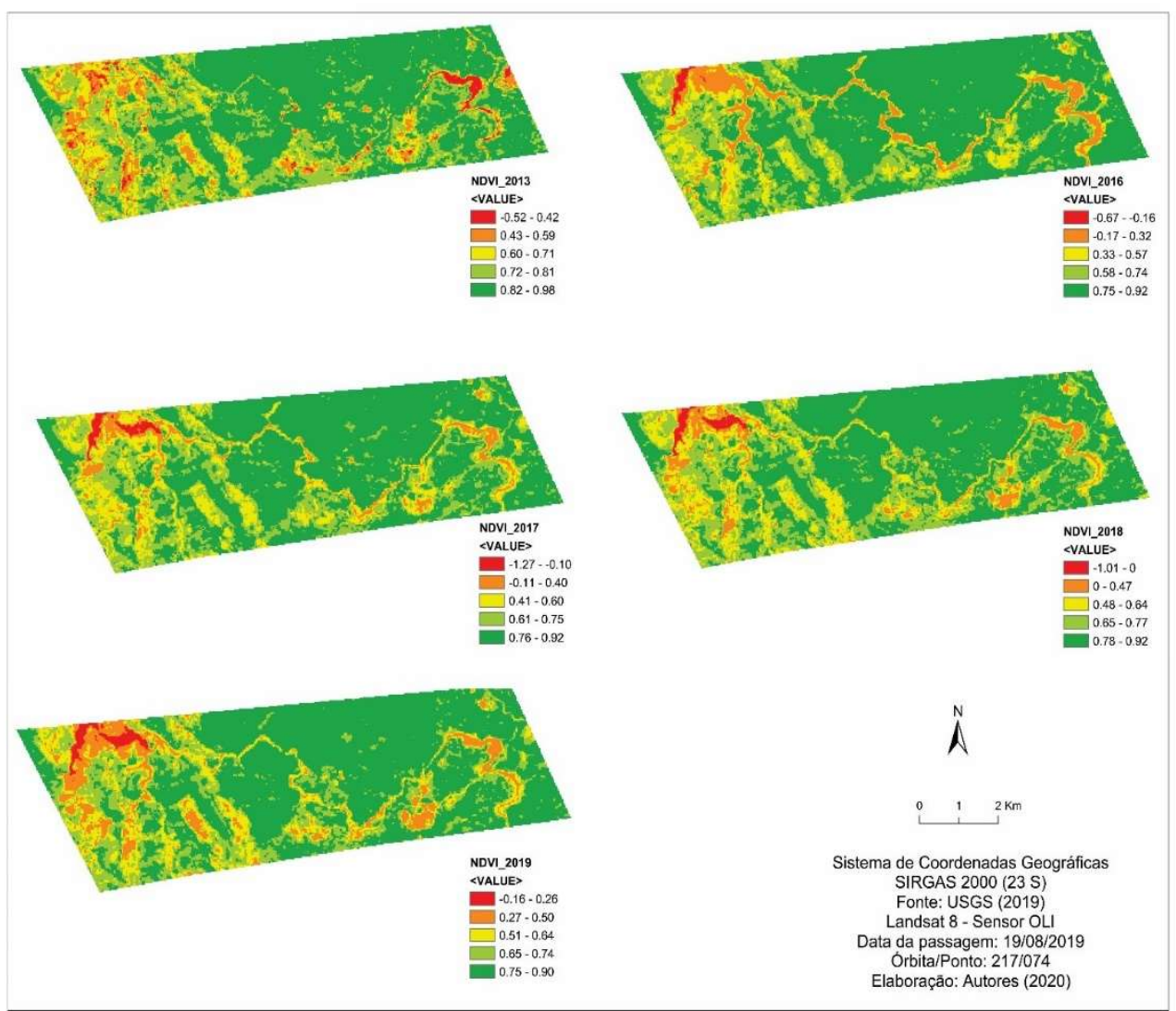

The result of the Friedman test indicated that the NDVI values showed statistically significant differences between the years covered - 2013, 2016, 2017, 2018 and 2019 - [X2 (4) $=528,205 ; \mathrm{p}<0.001]$. The multiple comparisons test determined that the years that showed no differences were 2016 and 2017, whereas the others showed statistically significant differences (Figure 08).

The 2013 spatial analysis served as a basis to understand the distribution of NDVI values before the dam was built, in which the presence of a clear body of water with a low amount of sediments was detected east of the Gualaxo do Norte River in the floodplain by the spectral response. This river before the dam burst was impacted with mercury and arsenic in the sediments, in addition to mining structures installed and in operation to extract gold (Rodrigues et al., 2007; Rholes, 2010). 
After the collapse of the Fundão dam, the environmental impact resulted in an even greater destruction for the surroundings, with vegetation and edaphic processes densely degraded and the fact that many species may not regenerate again due to the mineralogical changes in the environment. Such an impact is clear in the images of 2016 and 2017 and gradual regeneration of vegetation in 2018 and 2019. This evolution of the impact on regeneration is corroborated by the Friedman test.

In line with the statements of this study, Vieira (2019) showed that the regeneration of vegetation is occurring naturally, with the following families most present in the environment: Fabaceae, Euphorbiaceae, Asteraceae, and Malvaceae. In a pollen analysis carried out by the author, the herbaceous and shrub families were predominant in the trees, since they take longer time for regeneration and development.

Figure 08 - Multiple comparisons between pairs

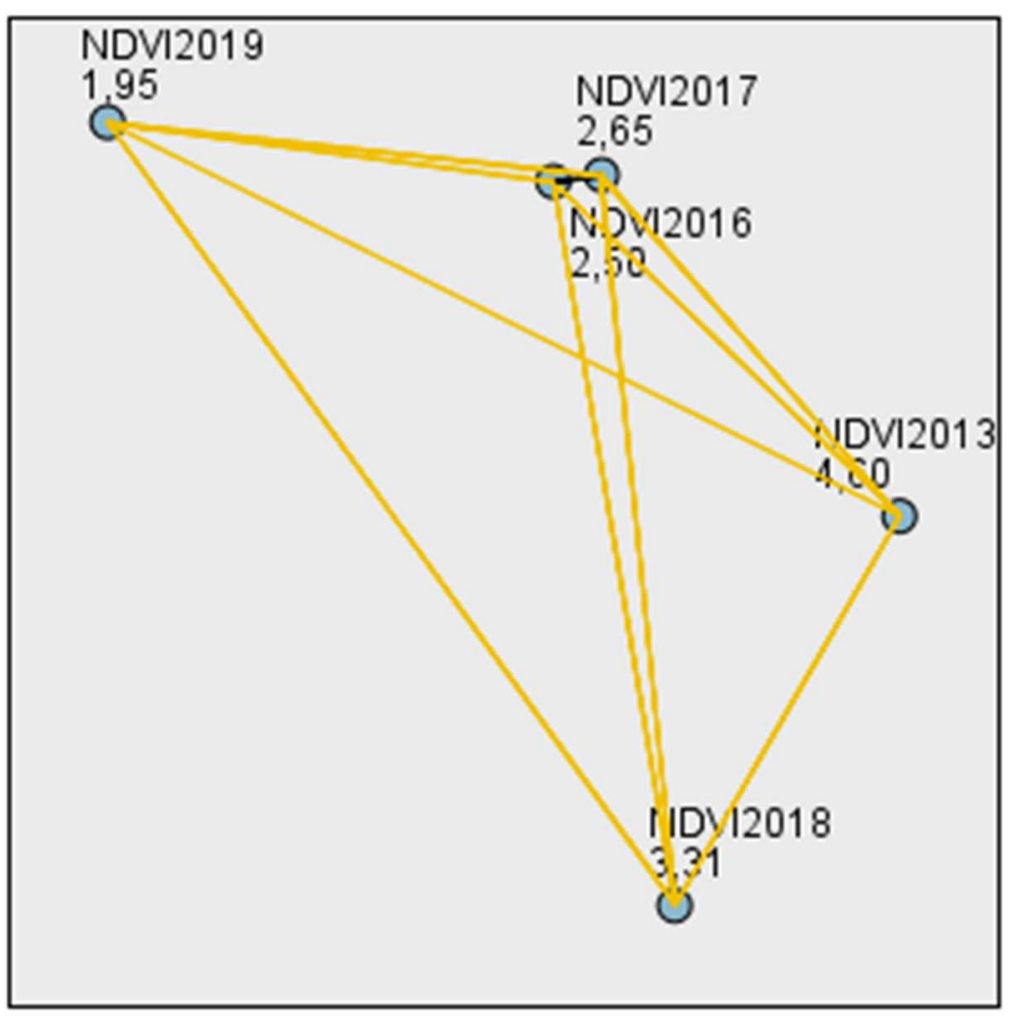

Thus, it became possible to analyze the impacted areas in the quadrant under study, the changes in spatial dynamics between the years 2013 and 2016 to 2019 through satellite images, and the NDVI vegetation index in order to identify areas with loss of vegetation and transport of tailings along the Gualaxo do Norte River. 


\section{Final Considerations}

The environmental disaster that occurred in Mariana City reveals one of the current problems in the face of the environmental crisis that has arisen and witnessed in the country. Therefore, all the economic return that the mining company Samarco grants to Minas Gerais State, Mariana City and its population, tends to be meaningless in the face of the disaster caused by the exploitation of minerals and socio-environmental damage. Not to mention the lives that they lost due to the event that occurred with the rupture of the dam, leaving a trail of destruction through the path covered by the mud of the tailings.

The constancy of the anthropization processes of nature are one of the contradictions of modernity, as they conceive the impasse of solving the difficulty found in environmental preservation and the sustainable use of natural resources. For the extraction of ore, mainly iron, the largest fluid constituent on the planet uses water on a large scale. Moreover, mining activity puts water resources at risk, among other essential elements for life on Earth. For this reason, the importance of the participation of society and public and private managers in the construction of a policy that reduces environmental risks is currently emphasized.

Through the study of the relief, it was possible to generate significant cartographic information for the analysis of the influence of the altimetric distribution in the entire extension of the tragedy. They were observed in the images after the rupture of the Fundão dam in the northwest portion between 2013 and 2016, which continues to reach tailings at the bed of the Gualaxo do Norte River. In this way, with the application of the vegetation index (NDVI), it is possible to observe the impacted area after the tragedy.

Thematic maps generated with the use of GIS are tools for analyzing future studies and provide information to managers for the creation of actions in order to mitigate situations such as what happened in Mariana City. The results obtained in this study carried out in an office show the dimension of the tragedy in the city, even though it is necessary to study in locu. Furthermore, the results achieved are shown to be positive to analyze the referred accident through satellite images and the vegetation index (NDVI) in order to identify areas with loss of vegetation and transport of tailings that head towards the Gualaxo do Norte River. 
The impacted area was presented visually through maps that are cartographic products generated to clearly present the impacted areas to public and private managers and society in general. Through the Geographic Information System (GIS), information regarding the change in the landscape and the destruction of the Bento Rodrigues District caused by the mud spill can be verified and visualized on the maps after the rupture of the Fundão dam which belongs to the Samarco Company located in Mariana City.

Therefore, it is necessary that other similar studies can contribute with results and suggestions that allow dialogue about the problems presented in this study.

\section{Acknowledgments}

The authors would like to thank the CAPES Foundation for the doctoral scholarships that allowed this study to be carried out and also the PGE-UEM for all its support.

\section{References}

BORGES, S. "O desastre da barragem de rejeitos em Mariana, Minas Gerais: aspectos socioambientais e de gestão na exploração de recursos minerais. " Cuadernos de Geografía: Revista Colombiana de Geografía 27301-312. doi: 10.15446/rcdg. v27n2.63008. [Acesso em 2020 jun 31], 2018.

BRASIL, Ministério do Meio Ambiente. Lei 12.334 de 20 de setembro de 2010. Estabelece a Política Nacional de Segurança de Barragens destinadas à acumulação de água para quaisquer usos, à disposição final ou temporária de rejeitos e à acumulação de resíduos industriais, cria o Sistema Nacional de Informações sobre Segurança de Barragens e altera a redação do art. 35 da Lei no 9.433, de 8 de janeiro de 1997, e do art. 4o da Lei no 9.984, de 17 de julho de 2000. Brasilia, 2010. Planalto, 2020. [Acesso em 2020 jun 31].Disponível em: http://www.planalto.gov.br/ccivil_03/_Ato2007-2010/2010/Lei/L12334.htm.

DANIELLOU, F. et al. Fatores humanos e organizacionais da segurança industrial: um estado da arte. [Acesso em 2020 mar 27].Disponível em: https://hal.archives-ouvertes.fr/hal00980776/, 2013.

FOESCH, M. D. S. Características físico-químicas e comportamento espectral de águas contaminadas por rejeitos de mineração: o caso de Mariana, MG. [Dissertação]. Universidade Federal Rural do Rio de Janeiro; 76, p. 2017.

FREITAS, W. K. de; MAGALHÃES, L. M. S. Métodos e parâmetros para estudo da vegetação com ênfase no estrato arbóreo. Floresta e Ambiente, v. 19, n. 4, p. 520-539. 2012. 
GONÇALVES, E. et al. Tragédia Evitável. Revista Veja. Minas Gerais, Edição. Minas Gerais, Ed. 2.452. Ano 48, $\mathrm{n}^{\circ}$ 46, p. 70-71. [Acesso em 2020 mar 28]. Disponível em: https://veja.abril.com.br/noticias-sobre/minas-gerais/, 2015.

INSTITUTO BRASILEIRO DE GEOGRAFIA E ESTATÍSTICA - IBGE. IBGE cidades. [Acesso em 2020 mar 01]. Disponível em: <https://cidades.ibge.gov.br/brasil/mg/mariana/panorama>, 2020.

LIBARDI, P. L.; MANFRON, P. A.; MORAES, S. O.; TUON, R. L. Variabilidade da umidade gravimétrica de um solo hidromórfico. Revista Brasileira de Ciência do Solo. v. 20, pp. 1-12. 1996.

LLORY, M.; MONTMAYEUI, R. O acidente e a organização. Belo Horizonte: Fabrefactum. 2014.

MARTIM, H. C.; SANTOS, V. M. Avaliação de impactos ambientais em empresa de mineração de cobre utilizando redes de interação. Revista Eletrônica em Gestão, Educação e Tecnologia Ambiental. v. 17, n. 17, p. 3246-3257. [Acesso em 2020 mar 15]. Disponível em: <https://periodicos.ufsm.br/index.php/reget/article/view/10382>, 2013.

MENDES, I. L. F.; ESPINDOLA, G. M. NDVI no estudo da área impactada pelo rompimento da Barragem de Fundão em Mariana-MG. Anais do Congresso Técnico Científico da Engenharia e da Agronomia. pp. 1-5. [Acesso em 2020 mar 08]. Disponível em: https://www.confea.org.br/sites/default/files/antigos/contecc2018/agrimensura/5_nned\%C3 \%A1iprdbdfem.pdf. 2018.

ORTIZ, J. L.; DE FREITAS, M. I. C. Mapeamento do uso da terra, vegetação e impactos ambientais por meio de sensoriamento remoto e geoprocessamento. Geociências (São Paulo). v. 24, n. 1, p. 91-104, 2007.

SILVA, G. F, Carvalho MVA, Cruz CBM. Análise espaço-temporal do desastre ambiental em Mariana-MG a partir das geotecnologias. Revista Continentes (UFRRJ). Ano 7, n. 13, pp. 4967, 2018.

RHOLES, V. P. Distribuição de mercúrio e arsênio nos sedimentos da área afetada por garimpo de ouro - Rio Gualaxo do Norte, Mariana, MG. [Dissertação]. Ouro Preto: Fundação Universidade Federal de Ouro Preto; 2010. p. 113.

RIBEIRO FILHO, M. R.; CURI, N.; SIQUEIRA, J. O.; MOTTA, P. E. F. Metais pesados em solos de área de rejeitos de indústria de processamento de zinco. Revista Brasileira de Ciência do Solo. v. 23, n. 2, pp. 453-464. [Acesso em 2020 mar 03]. Disponível em: https://www.scielo.br/scielo.php?pid=S0100-

$06831999000200028 \&$ script=sci_abstract\&tlng=pt,1999.

RODRIGUES, A. S. L.; MALAFAIA, G.; COSTA, A. T.; NALINI JÚNIOR, H. A. Adequação e avaliação da aplicabilidade de um Protocolo de Avaliação Rápida na bacia do rio Gualaxo do Norte, Leste-Sudeste do Quadrilátero Ferrífero, MG, Brasil. Revista Ambiente \& Água - An Interdisciplinary Journal of Applied Science. v. 7, n.2, pp. 1-14, 2012. 
SILVA, D. L.; FERREIRA, M. C.; SCOTTI, M. R. O maior desastre ambiental brasileiro: de Mariana (MG) a Regência (ES). Arquivos do Museu de História Natural e Jardim Botânico. v. 24, n. 112, pp. 136-158, 2015.

VIEIRA, K. I. C. Base de conhecimento para a meliponicultura: geração de renda e restauração ecológica nas comunidades atingidas pelo rompimento da Barragem de Fundão, em Mariana/MG. [Dissertação]. Viçosa-MG. (Mestrado em Manejo e Conservação de Ecossistemas Naturais e Agrários) - Universidade Federal de Viçosa; p. 204. 2019.

ZANZARINI, F. V. Correlação espacial do índice de vegetação (NDVI) de imagem Landsat/ETM + com atributos do solo. Revista Brasileira de Engenharia Agrícola e Ambiental. v.17, n.6, pp. 608-614, 2013. 